\title{
Owning Faculty Status: A Manifesto
}

\author{
Wyoma vanDuinkerken ${ }^{1}$, Catherine Coker $^{2}$, Todd Samuelson ${ }^{3}$ \\ ${ }^{1}$ Joint Library Facility, Texas A\&M University, College Station, USA; ${ }^{2}$ Research Services Cushing Library, Texas A\&M University, \\ College Station, USA; ${ }^{3}$ Cushing Library, Texas A\&M University, College Station, USA. \\ Email: wvanduin@library.tamu.edu
}

Received April $5^{\text {th }}, 2013$; revised May $13^{\text {th }}, 2013$; accepted June $28^{\text {th }}, 2013$

Copyright (C) 2013 Wyoma vanDuinkerken et al. This is an open access article distributed under the Creative Commons Attribution License, which permits unrestricted use, distribution, and reproduction in any medium, provided the original work is properly cited.

\begin{abstract}
Since the first moment librarians were granted tenured faculty status in the academic arena, questions have been raised by university and library administration, faculty members in other departments, and non-academics as to why they were given the opportunity to achieve such a prestigious rank. Not only did the majority of tenured/tenure track faculty librarians not have the standard doctorate degree possessed by most other tenured/tenure track faculty, but there were also questions surrounding the librarians' purported lack of teaching and their ability to perform original research as required for those tenure and promotion standards set by the academic institution. Sadly, this perception is due not only to incorrect external opinions about what academic librarians do and how they serve their profession but also to various internal library misunderstandings of what it means to be a tenured/tenure track faculty member. As a result of this misunderstanding, some librarians are unable to communicate what it means to be a librarian with tenured faculty status and thus the importance of academic freedom for their profession as a whole. This paper describes some key challenges tenured/tenure track faculty librarians face within their academic institutions as they attempt to grapple with what it means to be a librarian with tenured/tenure track status.
\end{abstract}

Keywords: Academic Library; Tenure; Promotion; Faculty Status; Academic Freedom

\section{Introduction/Rationale: What Is Tenured/Tenure Track Faculty Status?}

Tenure is seen as an employment agreement between an academic institution and an individual faculty member. The American Association of University Professors (AAUP) organization defines tenure as "an arrangement whereby faculty members, after successful completion of a period of probationary service, can be dismissed only for adequate cause or other possible circumstances and only after a hearing before a faculty committee" [1]. The 1940 AAUP statement continues to stress that "tenure is a means to certain ends; specifically: (1) freedom of teaching and research and of extramural activities, and (2) a sufficient degree of economic security to make the profession attractive to men and women of ability." Consequently, what tenure gives faculty members in academic institutions is not continual permanent employment in their positions but rather the protection of academic freedom while in their position.

\section{Faculty Rights: AAUP's Academic Freedom}

Academic institutions are created for the "common good and not to further the interest of either the individual teacher or the institution as a whole. The common good depends upon the free search for truth and its free exposition" [2]. The only way to achieve this common good is through the protection and promotion of academic freedom, which safeguards the academic institution's mission to expand the frontiers of knowledge. Academic freedom does this by protecting the faculty member from both internal and external pressures, when he/she expresses ideas or opinions which may be viewed by others as controversial. The 1940 AAUP statement of Principles on Academic Freedom and Tenure list the following as principles of Academic Freedom:

1) Teachers are entitled to full freedom in research and in the publication of the results, subject to the adequate performance of their other academic duties; but research for pecuniary return should be based upon an understanding with the authorities of the institution.

2) Teachers are entitled to freedom in the classroom in discussing their subject, but they should be careful not to introduce into their teaching controversial matter which has no relation to their subject. Limitations of academic freedom because of religious or other aims of the institution should be clearly stated in writ- 
ing at the time of the appointment.

3) College and university teachers are citizens, members of a learned profession, and officers of an educational institution. When they speak or write as citizens, they should be free from institutional censorship or discipline, but their special position in the community imposes special obligations. As scholars and educational officers, they should remember that the public may judge their profession and their institution by their utterances. Hence they should at all times be accurate, should exercise appropriate restraint, should show respect for the opinions of others, and should make every effort to indicate that they are not speaking for the institution.

What is particularly important for librarians is that use of the word "teacher" in the AAUP statement. Teacher is understood to include the investigator who is attached to an academic institution without teaching duties, which does include librarians with tenured faculty status. However, in 1946 the tenured faculty librarian profession was further protected when the American Library Association (ALA) official endorsed, adopted and adapted the AAUP's 1940 Statement of Principles on Academic Freedom and Tenure. ALA's version of the AAUP's statement is known as Tenure In Libraries: The Statement of Principles [3] and states that it "conform(s) in substance and insofar as applicable to librarianship to the 1940 statement of principles of tenure." This type of support continued and in the early 1970s, a significant number of academic universities as well as libraries and teaching faculty organizations recognized the merit of academic librarians, their high quality and essential work they perform for the academic institution. A number of these organizations appreciated how academic librarianship had advanced and changed over the years and how librarians continued to employ professional standards and academic rigor equivalent to traditional teaching faculty. Consequently, universities and professional organizations began supporting faculty status for librarians working at academic institutions, and in 1973 the AAUP, in conjunction with the Association of American Colleges and Universities (AACU) and the Association of College and Research Libraries (ACRL) released their Statement on Faculty Status of College and University Librarians. This statement called for academic universities to grant faculty status to librarians.

However, despite the mounting support from academic institutions, professional associations, and AAUP's clarification of what the word teacher in its 1940 statement entailed, academic librarians continued to be riddled with aproblem:the majority of librarians do little if any teaching in the traditional sense. This has continually caused heartburn for those teaching faculty and university administrators who do not understand how to evaluate the rigor of our Promotion and Tenure portfolios. Here at Texas A\&M University College Station (TAMU) for example, the basis of the University's promotion and tenure guidelines rest on the customary teaching, scholarship, and service model. However, as stated above, since the majority of librarians do not teach classes in the traditional sense, the Library College, with the support of the University Administration, modifiedthe promotion and tenure criteriafor librarians so that the librarians' contributions could be evaluated appropriately. As a result of this modification, the guidelines for a librarian's promotion and tenure case would rest on a model of librarianship, scholarship, and service. This "teaching vs. librarianship” difference continues to create some challenges for teaching faculty and university administrators since they simply do not understand what "librarianship" entails and how it is being evaluated to meet the same promotion and tenure standards as the rest of the academic teaching faculty (Coker et al.).

\section{Defending Our Academic Citizenship}

Adding to this frustrating obstacle is academic faculty librarians' owns truggle with what academic freedom is, why it is important to them, and how it relates to their profession. Instead of being vocal and defending our academic citizenship, some of our academic colleagues are blindly following our administrative leaders in leading the charge to dismantle tenure status because they simply don't understand what protections it gives tenured faculty and to the library itself. Librarians "must be able to think freely and independently, to test our practices and procedures, and to integrate our activities with the other instructional and research functions in our institutions. We have the responsibility to insist on the autonomy to do our jobs properly if we are indeed to be able to give the best service to our institutions" [4]. An academic library by its very nature requires free access to information on a variety of topics for the purposes of research by a university's students, faculty, staff and visitors. Like the faculty of other departments, the tenured/tenure track status protects the academic freedom of both librarians and thus the university collections - and thus the university entire.

In a recent conversation with another tenured librarian, I was expressing my concern that a tour own institution, the faculty librarians opened the discussion of possibly moving to a dual track system: one of tenured faculty status and the other utilizing a Clinical Faculty Librarian model which would allow those who decided to move to the Clinical Faculty status to keep faculty status but not tenure status: maintaining the letter but very much not the spirit of what it means to be university faculty. A specially-called faculty meeting with our Dean of Faculties further revealed the depth of the ignorance of some of our faculty members, including the belief that "our scho- 
larship does not contribute to the profession" and equating peer-reviewed articles with "term papers". Further, these were not the words of jaded long-term employees but those of junior faculty who clearly did not recognize the stakes at play in academia.

Admittedly, I am still confused what the catalyst was for the debate, but one thing was very clear to me: the lack of understanding of what it meant to lose the protection of academic freedom. I can proudly say that I was in the camp of librarians who wanted to keep their tenured faculty status and supported what Donald E. Riggs (1999) stated when he argued that those academic librarians who "do not want the responsibilities that go with [tenured] faculty status...should look for employment in an academic setting that does not require such". The pro-tenure group knew from previous experience and researchthat only faculty status with tenure could guarantee librarians' integration into the University's governance and academic spheres [5] as well as the protection of our academic freedom. A faculty vote was never taken on this topic. Shortly after this dual track system was discussed, our University, like most other universities, faced serious budget cuts. This gave the University an opportunity to create a voluntary retirement program in which over a hundred tenured faculty members participated in and led the various Colleges to lay off significant numbers of non-tenured track faculty members en masse-including clinical track faculty members and lecturers. However, because the budget cuts were not a result of the State of Texas calling for an emergency financial crisis, tenured faculty positions were protected from the cuts.

What surprised me the most about this discussion of tenure versus clinical tracks was that so few brought up the importance of academic freedom? Some people were concerned that, with the increase in workload, the continued pressure to publish was too much. Others even commented that our publications were not meaningful, describing them as little more than term papers. It was clear there was a misunderstanding of the importance of publishing and what academic freedom truly meant in our sphere.

However, TAMU Libraries is not alone in our struggle to understand the importance of academic freedom and how it protects academic librarians. Other academic librarians at peer tenure granting academic institutions are also asking similar questions, particularly as workload increases and library faculty hires decrease. During these internal discussions we need to keep in mind the common misunderstandings of what Academic Freedom is and remember what it protects for librarians. Over the past five years we have witnessed and researched a number of common misunderstandings of what Academic Freedom protects for Librarians.

- There is a misconception that Academic Freedom only protects our research activities. This in incorrect.

- There is a misconception that Academic Freedom only protects our collection development activities. This in incorrect.

- There is a misconception that Academic Freedom only protects our service activities. This in incorrect.

- There is a misconception that Academic Freedom does not protect us when we give Bibliographic Instruction classes since these types of classes are not classes in the traditional sense. This in incorrect.

- There is a misconception that Academic Freedom gives us job protection from being fired so we can do anything and our jobs will not be terminated. This is incorrect.

Not only are librarians entitled to freedom in research and in the publication of the results of their scholarship but we are also entitled to freedom to do the librarianship portion of our job-which is equivalent to the teaching responsibility of the traditional academic faculty members. For some librarians, librarianship may encompass reference, outreach, collection development, or instruction, while other librarians may be responsible for cataloging, acquisitions, or other "behind the scenes" duties. Despite these freedoms it is important to remember that, like the traditional teaching faculty, we must be careful when performing librarianship not to introduce controversial matters when they have no relation to the subject at hand, but at the same time be aware of those topical trends and discussions as they occur.

Being on the tenure track is not an easy road to take and there are a number of bumps along the way for many librarians. The two most commonly identified issues revolve around research and workload. Librarians on the tenure track know that publishing quality research takes: time, knowledge and experience. Since most librarians do not have methodological research training, they struggle with the writing process and often choose to focus on the librarianship portion of their job and postpone their publications. However, the tenure clock still ticks and before they know it, they are facing their tenure alarm with little to no research accomplished. Thus there is a rate of attrition among tenure-track librarians who leave and find jobs elsewhere or are stymied on the road to tenure due to problems in achieving this single goal.

Adding to this problem is the issue of workload. Unlike the teaching faculty members who not only define what they do by number of classes taught, number of students in those classes, and advising graduate students, librarianship is not as clearly definable through sheer numbers. For example, a cataloger's job is different than that of a reference librarian, a special collections curator is different than a subject specialist, a conservator is different than an electronic resources librarian, etc. How is one to compare volumes cataloged per month to instruc- 
tion sessions taught per month to reference questions answered per month in terms of institutional impact? Making the case for how to read such a variation in tenure packages becomes an issue very quickly.

\section{The Importance of Faculty Mentoring}

Possibly the most important aspect in the development of a scholar and the survival of academic freedom for tenured/tenure track librarians is that of mentorship. As stated above, one of the leading causes to begin the discussion of giving up academic freedom is work overload.

An academic mentor is not only someone who has completed the rigorous promotion and tenure process but an individual with whom the fledgling academic can create a social bond and work through their workload issues. A mentee simply needs someone to go to for advice with those issues each academic faces at some point in their careers, from the simplistic-how to select what conferences to attend or what journals to which to submit-but the more complex as well, like how to realistically balance work and home life. As Lee (2009) notes, "mentoring relationships allow individuals to pass on knowledge gained from work experience that cannot be taught strictly through an academic program” (31). Mentors not only supply the basic tools in surviving academe, but play a unique role in helping their mentees develop a professional philosophy or modus operandi of librarianship.

The most straightforward goal in all mentorship activities is that of employee retention: It is obviously in an institution's best interest to make sure that young librarians not only survive but thrive in the academic environment ${ }^{1}$. It is all too easy to forget in the daily grind of work that librarianship is not just a job but a literal application of scholarship. Every day, librarians use their subject expertise to select those materials that will be most valuable to their academic constituency and subsequently make them available for use. Every day, librarians create resources both print and electronic to assist students, faculty, and staff. Every day, librarians teachwhether before groups in a traditional classroom setting or one-on-one via interactions online or at a desk. As scholars, it is likewise imperative to remember that we not only educate our constituencies but that we educate ourselves as well: It is often taken for granted that continuing education is a serious component at all levels of library work. Workshops, seminars, and other instructional sessions make up a significant element of all librarianship conferences and meetings. Further, a significant percentage of library-related scholarship is educational articles on those programs and processes that have been successfully implemented at other institutions. Thus, even those librarians who do not work in the public

${ }^{1}$ See Kuyper-Rushing. sphere and maintain that they “don't teach” nonetheless do so regularly through those aspects of their work that involves instructing and assisting other librarians.

A good faculty mentor can help fledgling scholars identify those areas of inquiry of interest to the mentee not only professionally but academically. Further, the faculty mentorship model reiterates the importance of librarians as faculty functioning as advocates for one another. All too often, academia is viewed as a competition: who can publish the most, bring in the most grant money, and teach the best, etcetera ad nauseam. Through its very nature, the field of librarianship is a field that must be cooperative, flexible, and interdisciplinary-skills that are honed on the job but whose values can be reinforced by a mentor within the same sphere of the new librarian. Faculty advocating is not pleading the case for the specific person but rather for their specific role, whether it be as a subject specialist, a cataloger, an acquisitions and resources specialist, or an administrator. Due to the very wide range of expertise inherent in librarianship, not even all librarians inherently understand what their colleagues actually do for their department, and thus the need for a mentor who can act as something of a translator in assisting the new librarian in communicating their contributions to the greater cause.

As can thus be seen, there is a great deal for the new faculty librarian to absorb, and a great deal for a mentor to teach. Therefore the authors of this paper would like to offer a case of advocacy for our profession by providing a manifesto of how and what tenured academic librarians need to do to ensure their academic freedom.

\section{Manifesto: Protecting Academic Freedom for the Tenured Academic Librarian}

Our manifesto lays out six basic tenets for owning faculty status:

- In order for tenured academic librarians to sustain their academic freedom we need to understand not only what academic freedom is but why it is important, what it gives us, how it protects us and why we need to be protected by it.

- Tenure track librarians need to remember that we are teachers both of information access and of subject knowledge. Despite the fact that we might not teach the traditional scheduled course load, we teach all students and traditional academic faculty every day in various locations around university campuses and online. As a result, librarianship is protected under academic freedom.

- Tenure track librarians need to remember that we are keepers of physical and electronic resources and we must advocate and defend unconstrained research by facilitating free access to information, ideas and ma- 
terials. Without academic freedom, individual librarians are not protected and external pressures could lead them to purchase material that might be considered undesirable by students, staff, and university administration.

- Tenure track librarians can no longer afford to sit on the sidelines and allow other academic faculty (in and outside of the library) to fight for our academic rights. Nor can we afford to sit back and watch as library leaders disregard these rights saying "we are different and therefore that rule doesn't apply to us”. We need to stand up and become involved in faculty governance. We need to actively be involved, not only within the Library College and university level committees, but we must voice our opinions and rights nationally as a way of advocating for tenured faculty librarians rights to academic freedom.

- Tenure track librarians need to stop apologizing for not having a Doctorate of Philosophy. The research academic librarians produce is both applied and theoretical-and like other scholars in the academic arena we pass on knowledge to others in the library science field.

- Tenure track librarians need to think proactively to move the field of librarianship forward. We need to rely on their academic freedom and speak up against those library administrators who hold onto the archaic library services that are irrelevant to our users and cause an increase the workload for peers. Like teaching faculty, this increase causes librarians' workload to be too great for them to be effective in the organization.

Our joint-roles as intellectual guardians, scholars, instructors, advocates, collaborators, and most of all defenders are what underline the essential values of our discipline of library science.

\section{Conclusion}

Tenured/tenure track librarians are a rare breed among librarians and must remember they are faculty in every sense of the meaning. Like their counterparts throughout the university, they must have their voice heard in the academic arena so that they can address questions about the credibility of their tenured faculty status and end the incorrect external opinions about what academic librarians do and how they serve their profession. They also need to enlighten those tenured/tenure track librarians who misunderstand what it means to be a tenured/tenure track faculty member and communicate what it means to be a librarian with faculty status and the importance of academic freedom for the profession as a whole. If faculty librarians do not fully wish to own their status with all the obligations and privileges therein then they must accept the passive role on the sidelines of university governance, as well as those consequences that accompany it.

\section{REFERENCES}

[1] American Association of University Professors, "Tenure,” 2011. www.aaup.org/AAUP/issues/tenure/

[2] C. Coker, W. vanDuinkerken and S. Bales, "Seeking Full Citizenship: A Defense of Tenure Faculty Status for Librarians,” College \& Research Libraries 71.5, 2010, pp. 406-420.

[3] L. Kuyper-Rushing, “A Formal Mentoring Program in a University Library: Components of a Successful Experiment,” Journal of Academic Librarianship, Vol. 27, No. 6, 2001, pp. 440-446. doi:10.1016/S0099-1333(01)00258-0

[4] M. Lee, “Growing Librarians: Mentorship in an Academic Library,” Library Leadership \& Management, Vol. 23, No. 1, 2009, pp. 31-37.

[5] J. M. Welch and F. L. Mozenter, "Loosening the Ties That Bind: Academic Librarians and Tenure,” College \& Research Libraries, Vol. 67, No. 2, 2006, pp. 164-176. 